Original Research Article

\title{
Therapeutic drug monitoring of phenytoin using high performance liquid chromatography in a tertiary care hospital of Kashmir, India
}

\author{
Mohd Adil*, Sameena Farhat, Mohd Younis Rather
}

Department of Pharmacology, Government Medical College, Srinagar, Jammu and Kashmir 190010, India

Received: 22 February 2019 Accepted: 20 March 2019

*Correspondence to:

Dr. Mohd Adil,

Email: shahadil05@gmail.com

Copyright: (C) the author(s), publisher and licensee Medip Academy. This is an openaccess article distributed under the terms of the Creative Commons Attribution NonCommercial License, which permits unrestricted noncommercial use, distribution, and reproduction in any medium, provided the original work is properly cited.

\begin{abstract}
Background: Phenytoin is the most commonly used anti-epileptic drug (AED) in this set up due to cost effectiveness and easy availability. Significant fluctuations in serum phenytoin levels leading to toxicities or treatment failures make it an ideal candidate for therapeutic drug monitoring (TDM).

Methods: Patients of age $\geq 18$ years who were put on phenytoin were enrolled in this study. Estimation of serum phenytoin levels was done using HPLC. Data was analysed using SPSS version 20.0. Chi square test, Kruskal Wallis test were used to analyse the data.

Results: A total of 105 patients enrolled in the study, twenty patients (19\%) had normal or therapeutic serum phenytoin levels. Thirty-nine patients $(37.2 \%)$ had sub therapeutic serum phenytoin levels, while forty-six patients $(43.8 \%)$ had toxic serum phenytoin levels.

Conclusions: The TDM of phenytoin should adopt a multi-disciplinary approach with active involvement of neuro-physicians, pharmacologists, pharmacists and other technical staff for improving the overall management of epilepsy. TDM data will provide the clinicians with greater insight into the factors determining the patient's response to drug therapy.
\end{abstract}

Keywords: Epilepsy, HPLC, Phenytoin, TDM

\section{INTRODUCTION}

Therapeutic drug monitoring (TDM) is the clinical process of measuring the level of particular drugs at defined intervals to maintain a constant concentration in patients body fluids (plasma, serum or saliva), thus helping in the optimisation of individual drug therapy. Primarily TDM has a role in drugs with narrow therapeutic indices and marked pharmacokinetic variability. TDM is based on the assumption that there is a significant relationship between dose and body fluid concentration, and between concentration and therapeutic effects. ${ }^{1}$

Phenytoin is one of the most widely prescribed first line antiepileptic agents in the Indian population. ${ }^{2}$ Phenytoin (PHT) is used in the treatment of primary or secondary generalized tonic-clonic seizures, partial or complex partial seizures and status epilepticus. ${ }^{3}$ It is the most commonly prescribed AED in this set-up due to its cost effectiveness and easy availability. 4,5 
Long term repeated exposure to high serum concentration of phenytoin may predispose patients to irreversible neurotoxicity and may also exacerbate seizures. ${ }^{6}$ Thus, its administration requires a constant monitoring through what we call as therapeutic drug monitoring.

Selecting the most appropriate analytical methods is often not easy and the choice depends on the availability of staff, expertise and equipment, the nature of the service to be provided and the range of drugs to be assayed. The major advantage of chromatographic techniques is their flexibility and adaptability to a wide range of drugs. However, in comparison to immunoassays HPLC methods are slow, labour-intensive techniques which usually demand a high degree of technical expertise. Immunoassays have higher development costs than chromatography, narrow range of drugs to be analyzed and are generally more susceptible to interference to endogenous components (cross-reactivity). ${ }^{7}$

\section{METHODS}

After getting approval from the Institutional Ethics Committee, the study was conducted by the Department of Pharmacology in association with the Department of Neurology, Government Medical College, Srinagar, Jammu and Kashmir, India. The patients coming to the Neurology Department, SMHS Hospital were studied. All patients were on phenytoin $300 \mathrm{mg}$ daily in divided doses except 6 patients who were on phenytoin $400 \mathrm{mg}$ daily in divided doses. The participants were provided with explicit explanation for their inclusion in the study by instituting written informed consent, duly translated in local vernacular. It was a cross-sectional, observational study for a period of one and a half year.

\section{Inclusion criteria}

All patients with seizures of either sex and age group $\geq 18$ years of age who were prescribed phenytoin by the consulting physician were included in the study.

\section{Exclusion criteria}

- $\quad$ Patients who were unable to co-operate.

- Patients who were unable to give consent.

- $\quad$ Patients treated with traditional medicines alone.

- Patients with chronic illnesses like chronic liver or renal diseases.

\section{Procedure}

Estimation of serum levels of phenytoin was done using reverse phase high-performance liquid chromatography (RP-HPLC) from Agilent ${ }^{\circledR}$ technologies (1260 infinity series).

Data was entered in Microsoft Excel spreadsheet. Data was analysed using SPSS version 20.0. Data was analysed using SPSS version 20.0. Chi square test, Kruskal Wallis test were used to analyse the data.

\section{RESULTS}

Table 1 shows the age distribution of the study population.

Table 1: Distribution of the study population according to age.

\begin{tabular}{|lll|}
\hline Age $($ years $)$ & Frequency & Percent \\
\hline$<20$ years & 10 & 9.5 \\
\hline 21-40 years & 56 & 53.3 \\
\hline 41-60 years & 24 & 22.9 \\
\hline $61-80$ years & 15 & 14.3 \\
\hline Total & 105 & 100.0 \\
\hline
\end{tabular}

The mean age of the patients was 38.9 years with a standard deviation of 16.08 years. Most of the patients were in the age group of $21-40$ years $(53.3 \%)$ followed by the age group of 41-60 years (22.9\%), 61-80 years $(14.3 \%)$ and 18 20 years $(9.5 \%$ each $)$.

Table 2 shows the distribution of the study population according to sex. The study population comprised of 71 males $(67.6 \%)$ and thirty-four females $(32.4 \%)$.

Table 2: Distribution of the study population according to sex.

\begin{tabular}{|lll|}
\hline Sex & Frequency & Percent \\
\hline Male & 71 & 67.6 \\
\hline Female & 34 & 32.4 \\
\hline Total & 105 & 100.0 \\
\hline
\end{tabular}

Table 3: Distribution of study population according to serum levels of phenytoin.

\begin{tabular}{|lll|}
\hline Serum level of phenytoin & Frequency & Percent \\
\hline Sub therapeutic levels & 39 & 37.2 \\
\hline Normal (therapeutic) levels & 20 & 19.0 \\
\hline Toxic levels & 46 & 43.8 \\
\hline Total & 105 & 100 \\
\hline
\end{tabular}

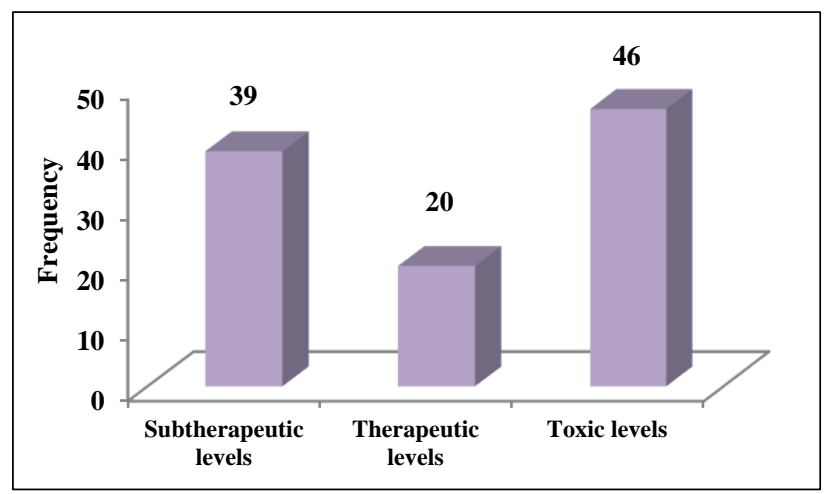

Figure 1: Frequency distribution of serum levels of phenytoin. 
Table 3 and Figure 1 shows the distribution of the study population according to their serum phenytoin levels $(\mu \mathrm{g} / \mathrm{ml})$. Out of a total of 105 patients enrolled for the study, only 20 patients (19\%) had normal or therapeutic serum phenytoin levels. 39 patients $(37.1 \%)$ had sub therapeutic levels, while 46 patients $(43.8 \%)$ had toxic levels.

\section{Table 4: Frequency distribution of serum phenytoin levels in study population.}

\begin{tabular}{|ll|}
\hline Statistical parameters & \\
\hline Mean & 23.83 \\
\hline Std. Deviation & 20.37 \\
\hline Minimum & 0.52 \\
\hline Maximum & 84.72 \\
\hline $25^{\text {th }}$ Percentile & 7.77 \\
\hline Median & 17.34 \\
\hline $75^{\text {th }}$ percentile & 38.08 \\
\hline
\end{tabular}

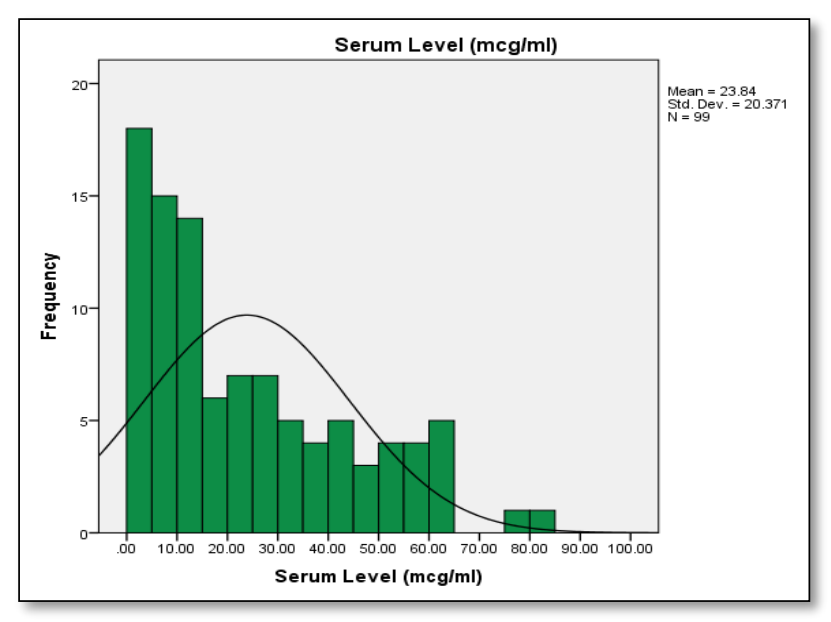

Figure 2: Frequency distribution histogram of serum phenytoin levels.

Table 4 and Figure 2 shows the frequency distribution of serum phenytoin levels in study population. The mean serum phenytoin level was $23.83 \mu \mathrm{g} / \mathrm{ml}$ (SD 20.37). Median of serum phenytoin level distribution in this study population was $17.34 \mu \mathrm{g} / \mathrm{ml}$ with a minimum and maximum of $0.52 \mu \mathrm{g} / \mathrm{ml}$ and $84.72 \mu \mathrm{g} / \mathrm{ml}$ respectively.

Figure 2 is a frequency distribution histogram showing the serum phenytoin levels in our study population of 105 patients. Majority of the patients $(79 \%)$ were outside the limits of normal serum phenytoin levels. The distribution is clearly not normal but a skew at the higher levels.

\section{DISCUSSION}

Phenytoin is an anti-epileptic drug approved for monotherapy and adjunctive therapy of tonic-clonic seizures and focal seizures in patients across all age groups, besides, it is used for treating seizures that occur secondarily to a neurosurgical intervention or severe head injury. In addition, phenytoin is one of the AEDs used in the management of status epilepticus. Other uses include the treatment of trigeminal neuralgia as a monotherapy and for the treatment of cardiac arrhythmias. ${ }^{8}$ Phenytoin is the most commonly prescribed AED in this set-up due to its cost effectiveness and easy availablilty. ${ }^{9}$

The present study was conducted in the Department of Pharmacology, Government Medical College, Srinagar, Jammu and Kashmir, India in collaboration with the Department of Neurology, SMHS Hospital, Srinagar, Jammu and Kashmir, India. Out of a total of 105 patients enrolled in the study, only twenty patients (19\%) had normal or therapeutic serum phenytoin levels. Thirty-nine patients $(37.2 \%)$ had sub therapeutic serum phenytoin levels, while forty-six patients $(43.8 \%)$ had toxic serum phenytoin levels.

Therapeutic drug monitoring (TDM) is done primarily to check drug toxicity, compliance and dose titration in drug therapy of epilepsy with various AEDs. Since, various AEDs have a narrow therapeutic index and significant pharmacokinetic variability, huge fluctuations in their serum levels can lead to either toxicity or therapeutic failure. The development of TDM for assessment of drug levels in various biological fluids like serum, plasma, saliva, etc. has now made it possible to study the interaction between drug dose, drug concentration in the body fluids, pharmacological effect and the net clinical outcome. ${ }^{9}$

Phenytoin has a narrow therapeutic range demanding a fine balance between therapeutic efficacy and dose related adverse reactions. Phenytoin exhibits a non-linear pharmacokinetic profile even within the therapeutic window, due to gradual saturation of the metabolising enzyme system, resulting in its decreased rate of elimination as dose increases. This means even a small change in the dose leads to wide fluctuations in the phenytoin levels in body fluids and hence variable clinical effect. The interindividual variability can lead to 50-fold difference in plasma/serum phenytoin concentrations in patients taking the same dose. All these factors make phenytoin an ideal candidate for TDM to ensure therapeutic efficacy. ${ }^{10}$

Estimation of serum levels of phenytoin was done in the Department of Pharmacology, Government Medical College, Srinagar, Jammu and Kashmir, India using Reverse phase high-performance liquid chromatography (RP-HPLC) from Agilent ${ }^{\circledR}$ technologies (1260 infinity series). Selecting the most appropriate analytical methods is often not easy and the choice depends on the availability of staff, expertise and equipment, the nature of the service to be provided and the range of drugs to be assayed. The major advantage of chromatographic techniques is their flexibility and adaptability to a wide range of drugs. However, in comparison to immunoassays, HPLC methods are slow, labour-intensive technique which usually demand a high degree of technical expertise. Immunoassays have higher development costs than chromatography, narrow 
range of drugs to be analyzed and are generally more susceptible to interference to endogenous components (cross-reactivity). ${ }^{7}$

Present study enrolled a total of 105 patients as study population. A study conducted by Lascelles PT et al, enrolled 111 patients in their study. ${ }^{11}$ Similarly, Houghton GW et al, enrolled 170 patients in their study, Garg SK et al, enrolled 116 patients in phenytoin group in his study 'TDM of antiepileptic drugs-a preliminary experience', while as a study conducted by Dahiya $\mathrm{K}$ et al, enrolled 1255 patients on phenytoin monotherapy in their study. ${ }^{9,12,13}$

Most of the participants in the study were in the young and middle age groups of $21-40$ years $(53.3 \%)$ and $41-60$ years (22.9\%), followed by $61-80$ years $(14.3 \%)$ and $18-20$ years (9.5\% each), with a mean age of 38.9 years (SD 16.08 years). A study conducted by Lertsinudom $\mathrm{S}$ et al, had a mean age of 38.21 years (SD 15.36). ${ }^{14}$ Another study conducted by Rasheva $M$ et al, had a mean age of 42.2 years (SD 20.3). ${ }^{15}$ The study population comprised of 71 males $(67.6 \%)$ and thirty four females $(32.4 \%)$, with a male:female ratio of 2.08. Dahiya K et al, had $63.8 \%$ males and $36.12 \%$ females enrolled in their study with a male: female ratio of $1.77 .^{9}$

Out of a total of 105 patients enrolled in the study, only 20 patients $(19 \%)$ had normal or therapeutic serum phenytoin levels. 39 patients $(37.1 \%)$ had sub therapeutic levels, while 46 patients $(43.8 \%)$ had toxic levels. The mean serum phenytoin level was $23.83 \mu \mathrm{g} / \mathrm{ml}$ with a standard deviation of $20.37 \mu \mathrm{g} / \mathrm{ml}$. A similar study conducted by Lascelles PT et al, showed a wide scatter of serum levels of phenytoin with around $55 \%$ of patients outside the normal limits. ${ }^{11} 19 \%$ were in the sub therapeutic range and $36 \%$ were in the toxic range. Another study conducted by Dahiya $\mathrm{K}$ et al, found only $26.4 \%$ patients with serum phenytoin levels in therapeutic range. ${ }^{9}$ The major proportion of patients had serum phenytoin levels in the sub therapeutic range $(51.6 \%)$ and toxic range $(20.6 \%)$. Garg SK et al, in their study found that in patients of phenytoin group, $38(32.8 \%)$ had therapeutic levels, 63 $(54.3 \%)$ had sub therapeutic levels, $12(10.3 \%)$ had toxic levels and $3(2.6 \%)$ had undetectable levels of the drug. ${ }^{13}$

The effect of various demographic factors like age, sex, body weight and height on serum phenytoin levels was analysed in this study. There was a statistically insignificant relationship between serum phenytoin levels and the age (years) of the patient with a $\mathrm{p}$ value $=0.268$. Relationship between serum phenytoin levels and the sex of the patient was seen to be statistically significant, although not strong, with a $\mathrm{p}$ value $=0.042$. The serum phenytoin levels were lower in females in comparison to males. There was a very weak and insignificant correlation between serum phenytoin levels $(\mu \mathrm{g} / \mathrm{ml})$ and bodyweight $(\mathrm{Kgs})$ with $\mathrm{r}=0.08$ and a $\mathrm{p}$ value $=0.288$. Similarly, a very weak and insignificant correlation was seen between serum phenytoin levels $(\mu \mathrm{g} / \mathrm{ml})$ and body height $(\mathrm{cm})$ with $\mathrm{r}=0.176$ and a $\mathrm{p}$ value $=0.053$. A study conducted by Houghton GW et al, found that serum phenytoin levels showed a positive correlation with age, negative correlation with body weight and height, and when corrected for body weight and height, the serum phenytoin levels in women were lower than those in men, although the difference was not statistically significant. ${ }^{12}$

Travers RR et al, reported that women had a lower mean serum phenytoin concentration than men treated with an identical dose per $\mathrm{kg}$ of body weight, although the difference was not statistically significant. ${ }^{16}$ The differences in results in this study cannot be explained clearly. Ethnicity, genetic makeup and variation in analytical technique and method used can be the possible reasons.

\section{CONCLUSION}

The present study is first of its kind to be conducted in this set up. The therapeutic drug monitoring of phenytoin and/or other AEDs should adopt a multi-disciplinary strategy with active involvement of physicians, pharmacologists, pharmacists and other technical staff for improving the overall management of epilepsy and subsequently reducing the burden of ADRs. Cooperation from clinicians and adequate knowledge and proper training of the technical staff is the need of hour. Holistic patient discussions and assurance need to be followed. TDM data will provide the clinicians with greater insight into the factors determining the patient's response to drug therapy. The overall aim of such studies should be individualisation of treatment or what we call "tailor made therapy", besides diagnosing/avoiding toxicity, assessing compliance and monitoring treatment outcome. Use of TDM must be expanded to other drugs with narrow therapeutic range and potential toxicities.

\section{Funding: No funding sources Conflict of interest: None declared \\ Ethical approval: The study was approved by the Institutional Ethics Committee}

\section{REFERENCES}

1. Kang JS, Lee MH. Overview of therapeutic drug monitoring. Korean J Internal Med. 2009;24(1):1.

2. Rosemary J, Surendiran A, Rajan S, Shashindran $\mathrm{CH}$, Adithan C. Influence of the CYP2CP and CYP2C19 polymorphisms on phenytoin hydroxylation in healthy individuals from south India. Ind $\mathrm{J}$ Med Res. 2006;123(5):665.

3. McNamara JO. Pharmacotherapies of the epilepsies. In: Brunton LL, Lazo JS, Parker KK, eds. Goodman and Gilman's The Pharmacological Basis of Therapeutics. 11th ed. New York: McGraw Hill; 2006: 501-526.

4. Krishnan A, Sahariah SU, Kapoor SK. Cost of epilepsy in patients attending a secondary-level hospital in India. Epilepsia. 2004;45(3):289-91. 
5. Krishnan RA, Chowdhury D. Cost of antiepileptic drugs in India. Neurol Asia. 2007;12(1):42-3.

6. Reynolds EH, Trimble MR. Adverse neuropsychiatric effects of anticonvulsant drugs. Drugs. 1985;29(6):570-81.

7. Dodig S. Interferences in quantitative immunochemical methods. Biochem Med. 2009;19(1):50-62.

8. Patsalos PN, Spencer EP, Berry DJ. Therapeutic drug monitoring of antiepileptic drugs in epilepsy: a 2018 update. Therapeutic Drug Monitoring. 2018;40(5):526-48.

9. Dahiya K, Bansal P, Ghalaut VS, Dhankhar R, Ghalaut PS. Therapeutic drug monitoring for antiepileptic drugs using HPLC: an experience at a tertiary care hospital in India. Neurol Asia. 2010;15(3).:233.

10. Wu MF, Lim WH. Phenytoin: a guide to therapeutic drug monitoring. Proceedings Singapore Healthcare. 2013;22(3):198-202.

11. Lascelles PT, Kocen RS, Reynolds EH. The distribution of plasma phenytoin levels in epileptic patients. J Neurol Neurosurg Psychiatry. 1970;33(4):501-5.

12. Houghton GW, Richens A, Leighton M. Effect of age, height, weight and sex on serum phenytoin concentration in epileptic patients. Brit $\mathrm{J}$ Clin Pharmacol. 1975;2(3):251-6.

13. Garg SK, Gupta MC, Handu SS, Bhargava VK. Therapeutic drug monitoring of antiepileptic drugs-a preliminary experience. Ind J Pharmacol. 2000;32(1):28-30

14. Lertsinudom S, Chaiyakum A, Tuntapakul S, Sawanyawisuth K, Tiamkao S. Integrated Epilepsy Research Group. Therapeutic drug monitoring in epilepsy clinic: a multi-disciplinary approach. Neurol Int. 2014;6(4).

15. Rasheva M, Staikov I. Low serum levels of antiepileptic drugs in patients with epilepsy-Bad compliance or something else. Austin J Clin Neurol. 2015;2(10):1083.

16. Travers RD, Reynolds EH, Gallagher BB. Variation in response to anticonvulsants in a group of epileptic patients. Arch Neurol. 1972;27(1):29-33.

Cite this article as: Adil M, Farhat S, Rather MY. Therapeutic drug monitoring of phenytoin using high performance liquid chromatography in a tertiary care hospital of Kashmir, India. Int J Basic Clin Pharmacol 2019;8:995-9. 